area with the time of day and with the season, the limitation of the service by noises of natural origin --mainly radiated from lightning flashes-all these and similar factors lead to keen competition for wave-length channels, which must be allocated internationally if radio peace is to be maintained.

It has been suggested that allocation should be based on two principles which seem unanswerable in the abstract, but which have not yet been accepted as a basis of action. The first principle is, in its broadest form, that first claim should be conceded to those services in which a metallic conductor cannot be used to link sending to receiving station. Thus maritime and aireraft services would be given absolute priority; and the use of line telegraphy and telephony would be encouraged, in preference to radio links, wherever they could assure a service. The second principle is that where services with a legitimate claim (within the first principle) to radio allocations come into competition for channels, preference should be given to the one which is of the highest social importance. In the absence of an agreed set of principles such as these, allocation has remained a matter for bargaining, compromise and successive readjustments. Difficult as would be the working out of the ethical, organizational and political problems implicit in the "highest social importance" criterion, the absence of even this golden foot-rule leaves still greater difficulties to be faced. Prestige, propaganda and profits are noisier claimants than principles.

The maritime services demand not merely straightforward communication of the content of the spoken or the written word, not merely that vital aid to determination of longitude provided by time signals, the value of which depends on the infinitesimal time they lose in travelling halfway round the world. They require, too, those radio aids to navigation which depend on the fact that it is not difficult to measure, at a receiving station on ship or shore, the bearing, relative to true north or to the ship's heading, from which signals of known place of origin are coming in. Radio beacons and direction-finding services require a special place in the most-favouredservice category.

Still more exacting are the claims of air transport. Radio, with its lusty infant progeny of 'radar' devices, offers the air line of the immediate post-war future a complex of communication, navigational and safety services which leave only one major hazard in all-weather flying. But such services demand monopoly use of a considerable range of wave-lengths, denied to any other user within a wide area which may, in some cases, be a world area.

These are the services which would stand indisputably at the top of the priority list based on the first general principle; the broadcasting services would certainly claim first place in the "social importance" scale-even though the cynic will sug. gest that a mad dog may, while he runs free, be of more immediate social importance than a young Pasteur.

It is not too soon for the United Nations to be considering now a sound double framework of basic principles and technical performance in the broad field of international communications. Within such a framework must be fitted the post-war solutions of problems which will have become more numerous and more pressing with war-time progress in radio and with the demands of rehabilitation. It may well be believed-and hoped-that no such opportunity for rationalization and reconciliation of competing claims in the field of international communications will ever again present itself.

\section{NATURE CONSERVATION AND ECOLOGY}

T his recent broadcast address, the Prime Minister 1 rebuked those "comfortable people who ... would rather postpone building homes for the returning troops until they have planned out every acre in the country to make sure the landscape is not spoiled". It is not, perhaps, immediately clear who are the people thus referred to, but we can be sure that the scientific advocates of nature conservation are not among them. They, at any rate, will be content if the place allotted to them in the scramble for post-war priorities is not too near the end of the queue. This is made clear in an admirable pamphlet recently published by the British Ecological Society*, in which the human or social background is constantly kept in view.

When the Nature Reserves Investigation Committee was appointed in response to an official request in 1942, a committee of the Ecological Society was already engaged in considering the same subject and was able to assist in the inquiries. When the first-named Committee's report was published (see Nature, June 26, 1943) the work of the Ecological Committee might have been thought to require no further record. It was considered, however, that the distinctively ecological point of view deserved to be independently formulated, and the report now published is designed to do this. It forms a very valuable supplement to the earlier report, and its extended treatment of the subject may be found more attractive by many readers.

Ecologists are, of course, primarily concermed with the scientific (or research) and educational aspects of nature conservation, though it is emphasized that these only rarely conflict with, and often reinforce, the claims of amenity and recreation. The subjects of ecological study are less the individual species than the interdependent aggregations or 'communities' of animals and plants that occur in Nature, and ecologists are specially desirous of preserving these communities. "Oak, beech and ash trees, heather and bilberry and bog-moss are very unlikely to disappear altogether from the country, but their continued existence as species is of very limited use to the ecologist if all the oakwoods, beechwoods and ashwoods, the heather and bilberry moors and the undrained Sphagnum bogs are destroyed or so modified that they no longer

" "Nature Conservation and Nature Reserves". Report drawn up by Society. Pp. 38. October 1943. (Cambridge University Press.) 18. 6d. 
represent natural plant communities." For this reason the ecologists regard with some suspicion the term 'species reserves' given 'by the Nature Reserves Investigation Committee to the category of reserves intended to secure the survival of rare or very local species. In every case it is the habitat rather than the individual species to which the conservators must direct their efforts, and 'species reserves' are simply 'habitat reserves' differing from others in the same category only in the reasons for their selection.

'The ecologists distinguish between 'natural' and 'semi-natural' communities of plants, with their associated animals, and point out that efforts at conservation should embrace the latter as well as the former. For example, in the southern parts of the British Isles, hedgerows and small copses provide the main habitat for many species of wild flowers and nesting sites for perhaps the majority of our smaller birds. Their destruction, advocated and perhaps inevitable in the interests of large-scale mechanized farming, would not only destroy much of the charm of the lowland countryside but also might have indirect effects harmful in the long run to agriculture, such as the elimination of insectivorous birds and even the erosion of the lighter soils by wind or water.

It may perhaps be doubted whether the distinction drawn by the ecologists between 'natural' and 'seminatural' communities is of much practical significance in Great Britain. Communities which are 'natural', in the sense that they owe none of their features to the effects of human activities, are probably very rare and are to be looked for only on the tops of the highest mountains and the wilder parts of the sea. coast. Further, the distinction is not always consistently adhered to even in the Ecological Committee's report itself. Thus, on p. 8 , the rough grazings of hill pastures "which have never been ploughed or manured" are stated to consist of "entirely wild vegetation", while on p. 4 it is stated that "most of the grassland of these hill grazings owes its present condition largely to the continual nibbling of sheep". It may be added that land which is constantly grazed can scarcely be described as never having been manured.

That part of the report which deals with the relation of nature conservation to the activities of the Forestry Commission is of particular interest. In view of the urgent national need for coniferous timber, it is inevitable that the chief attention of the Commission must be devoted to supplying this. Coniferous plantations are admittedly not picturesque, and their associated fauna and flora are impoverished and lacking in interest to the ecologist, although "the plantations will lose much of their repellent uniformity and ecological poverty as they grow older". The report notes with satisfaction, however, that the Commission has not lost sight of more remote interests, as, for example, in setting aside as 'permanent forest reserves' certain areas of old, undisturbed, deciduous woodland, and it sug. gests that the Commission might be given a broader mandate to enable it to deal with questions at present excluded from its scope.
The Ecological Committee takes a similarly realistic view of the relations which should obtain between nature conservation and agriculture and game preserving. In connexion with the last-named subject, the Committee rightly deprecates attempts to introduce exotic species of animals. Its condemnation might have been more emphatic. In the past, such introductions have been mostly due to the whims of individual landowners; but it is a regrettable fact that even to-day one does occasionally meet people whose idea of a nature reserve seems to be a com. bination of Whipsnade with the less formal parts of Kew Gardens.

As regards the administrative machinery which it would like to see set up for the establishment and supervision of nature reserves, the Committee of the British Ecological Society cordially endorses most of the recommendations of the Nature Reserves Investigation Committee. While the latter, however, looks forward to the institution of a national nature reserves authority under the Ministry of Town and Country Planning, the Ecological Committee would like to see a national wild-life service with a status similar to that of the Medical Research Council, under the Privy Council, to embrace the whole field of the native fauna and flora of Great Britain. To this, presumably, would have to be added the conservation of geological sites advocated by the Nature Reserves Investigation Committee. Doubtless we may have to wait a long time to see the full develop. ment of such large-scale plans, but meanwhile there is much that might be done to educate the general public in the meaning and methods of nature conservation. For this purpose the pamphlet issued by the British Ecological Society deserves a wide circulation.

\section{WHALEBONE WHALES IN THE ANTARCTIC}

The Southern Stocks of Whalebone Whales

By Dr. N. A. Mackintosh. (Discovery Reports. Issued by the Discovery Committee, Colonial Office, London, on behalf of the Government of the $\mathrm{De}$ pendencies of the Falkland Islands.) Pp. 197-300. (Cambridge: At the University Press, 1942.) $15 s$. net.

THE main object of the research conducted by the "Discovery" Committee is the investigation of the biology of the economically valuable whales frequenting Antarctic waters. A number of "Discovery" reports dealing with various aspects of the subject have already been published, and Dr. Mackintosh's present paper incorporates much of this material in a comprehensive survey of pre-war conditions. At the present time, whaling is at a standstill, and the stock of whales is enjoying a respite from pursuit likely to extend to the end of the War. The effect of this war-time period of protection can only be measured comparatively in terms of conditions prevailing when whaling ceased. From this aspect, Dr. Mackintosh's review is of particular value. It should be emphasized that his memoir is by no means merely a compilation of already published data. It contains a great body of additional informa. 